
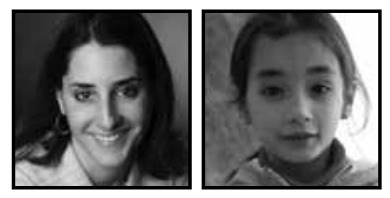

\title{
Musings on the Neurobiological and Evolutionary Origins of Creativity via a Developmental Analysis of One Child's Poetry
}

\author{
Mary Helen Immordino-Yang, University of Southern California, \\ with Nora Ming-Min Yang
}

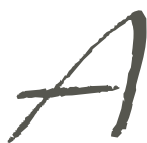

s Antonio Damasio and I discuss in the article, "We Feel, Therefore We Learn: The Relevance of Affective and Social Neuroscience to Education" (MBE, 2007), all human thoughts and actions, and especially creative or innovative thoughts and actions, bear the shadow of the brain's original, evolutionary purpose-to keep one's body alive and functioning comfortably, efficiently, and appropriately in the world. Although neuroscience may simply confirm what experience has taught us, the evidence is plain. Our brains sense the insides of our bodies not only to regulate their mechanics, for example to adjust blood pressure and digestion appropriately to maintain our health, but also to play out the subjective, experiential dimensions of our social and emotional lives. We think something, consciously or not, and sometimes our brains adjust our physiology to reflect the emotional implications of that thought. Then, we may feel back the results of those embodied changes, as a source of information about our own reaction. Neuroimaging experiments show us that we use the very same neural systems to feel our bodies as to feel our relationships, our moral judgments, and our creative inspiration. We really do live by "gut feelings," and of course these gut feelings are induced and felt by our brains in accordance with our beliefs, experience, and knowledge.

And yet, you might ask, what sense does it make to put creativity on an equal footing with survival? How, for example, could anyone find comfort and efficiency in crawling into a damp black cave in southern France to spit chewed pigments on entombed rock faces in patterns portraying wild beasts? Or how could a contemporary human find fulfillment in gazing at a gibbous moon on a clear night, wondering about the other side and what the view from there might be like, staring 
off into the blackness of space? And aside from how humans could do these things, why do we feel compelled to do them?

The short answer is that, as we became the most socially interdependent mammals known to exist, the mechanisms we evolved to survive in the physical world seem to have been co-opted to manage our well-being in the social world. Survival in the savanna depends on a brain that is wired to make sense of the environment, and to play out the things it notices through patterns of bodily and mental reactions. Something catches our eye; we feel a jolt of adrenaline. Is that a poisonous snake or a vine? This same brain, the same logic, helps us make sense of and survive in the social world of today. Does that look on my teacher's face suggest displeasure or approval? Will this poem I have written convey to others the essence of my experience? With all the inter-relating and mind-reading and empathizing that we do with each other, and even with the moon when we so indulge ourselves, comes a drive to express ourselves, to understand and move others to live something from our own life, to assign meaning and purpose to the activities we engage in, the products we create, and the concepts we learn. The health of our social identity is every bit as important as our physical well-being because we feel them both on the same neural platforms. Why did that cave painter slither along that dank rock on his belly in the dark? Perhaps it had something to do with the satisfaction that comes from immortalizing one's own experiences, from affirming one's self by representing the feelings and thoughts witnessed by that self for someone, sometime, to see. After all, behind every painting or poem or essay or physics equation is a painter, a poet, a writer, a physicist. A real person, alive in both the biological and sociocultural senses, who is hoping to influence others' understanding by virtue of representing her own. What current neuroscience findings are showing us is that the feeling of creating, the satisfaction it provides, may get its inspirational power by virtue of its connections to the mechanisms that promote and feel our bodily survival and satisfaction, in the most basic, literal sense.

The poems included here provide an anecdotal but instructive example of how one child's developing understanding of the physical and social worlds are intertwined as she creates, just as they must have been for that mysterious cave painter from long ago. These poems were written on her own, just because she wanted to write them. You might even assert that she was compelled to write them, by virtue of the evolutionary origins of her modern, social mind. Because just like all humans before this young author, and all who will come, what social and affective neuroscientific studies are revealing is that the legacy of our intelligent brain is our social mind. By virtue of its evolutionary connection to bodily feeling and survival, our social mind motivates us to create things that represent the meaning we have made by processes 
of noticing, feeling, and understanding, so that others can notice and feel and understand what we have. While of course our bodies can no sooner live without food and water and warmth than they ever could, food, water, and warmth alone are no longer sufficient for us. Our biological drives are co-opted over the course of cognitive development into a platform for making sense of the world in increasingly complex ways. We must understand, we must know, we must share our experiences. What follows is an analysis of one girl's maturing attempt to do these things.

\section{Poem 1. Untitled, Age 6 Years, 2 Months.}

Oh Teddy we love you mor then the whole rth sis as the rth spins evry day we love you as much as u shewell but sum timse evine mor as you mac us proud and happy tha chyr you!

[Oh Teddy we love you more than that whole Earth Size. As the Earth spins every day we love you as much as usual, but sometimes even more, as you make us proud and happy that you're you!]

This poem was written as a song, with a melody, and was accompanied by a drawing of the author with a music stand singing to her brother, Teddy. What I love about this poem (song) is that it demonstrates so nicely the interdependence of emotion and even rudimentary disciplinary knowledge in learning. How does this little girl express the love and pride of her family for her little toddler brother-the love that she feels both biologically and socially? She references her newly acquired, simple knowledge of planetary science. She likens the vastness of her feelings to the size of the biggest thing she can think of - the Earth, and the endurance of the family's love over time to the constancy of the Earth spinning to make days. In the end, this is both a poem about a family's love for their baby, and one about the author's understanding of the planet she lives on. 


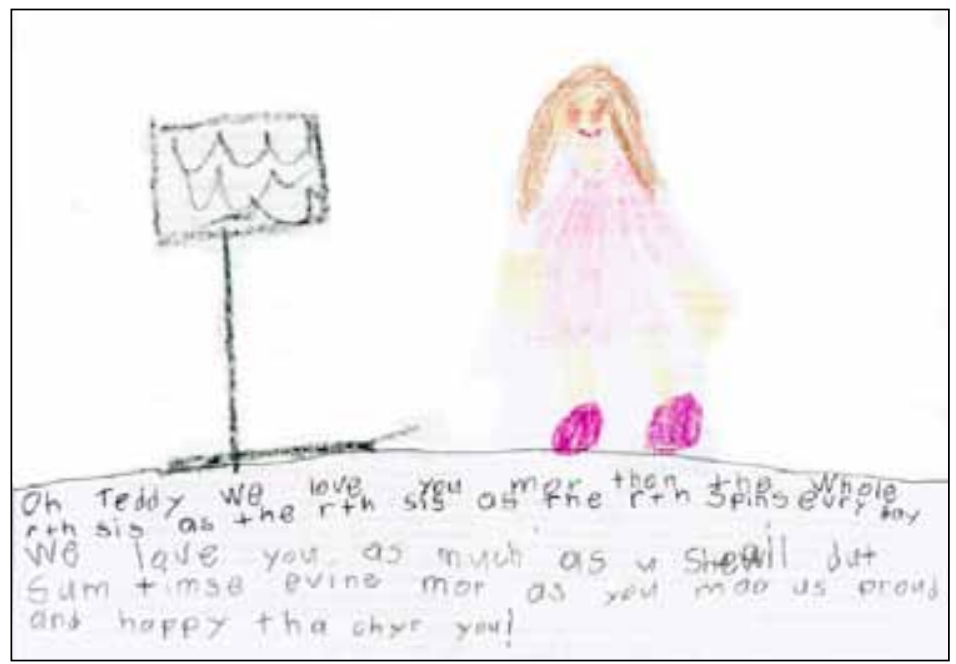

Fig. 1: Poet's artwork

\section{Poem 2. Age 7 Years, 3 Months.}

\section{Universe}

The stars are floating around the earth.

As the earth looks so peasfull, there are no wars right now, and rainbows are shining as the clowds are mooving. What a butifull sight.

The end.

In this poem, the author treats us to a vision of the world, observed from the perspective of the stars. As in the first poem, her descriptions of the planet are imbued with social emotions about the value of peace. From a developmental perspective, though, the author has gained a more complex ability to represent multiple ideas at once, as well as a clearer literary structure for the poem (that is, she frames the poem between a title and a closing). She presents us with one "beautiful sight" but grounds her idea in several pieces of evidence, all simultaneously true: the lack of wars, the shining rainbows, and the moving clouds. She titles the poem using the grandest concept she can think of, and, just as poets have for generations, she turns to her rudimentary knowledge of astronomy for inspiration. 


\section{Poem 3. Age 8 Years, 10 Months.}

\section{Let Love Flow Through You}

(a poem for January)

There is a child

snuggled down for a good winter nap

Let him sleep peacefully

Let him blink silently

Let his mother's love flow through him

Don't wake him

This poem was written as part of a book that included one poem for each month of the year, given to the author's mother as a holiday present. In this poem, the first in the series, the author writes of a sleeping child. She takes the perspective of an omniscient onlooker, instructing the reader not to disturb the child's slumbers because even this simple action of sleeping is permeated with evidence of the child's close relationships-his mother's love flowing through him. Interestingly, the author titles the poem with a command to the reader, as if she can now mentally represent that her poems have a purpose-they can communicate her ideals to another person, the reader, and teach a lesson in the process. Her command of language is improving also, demonstrated by the alliterative repetition of the word "let" in the parallel structure of the middle lines.

\section{Poem 4. Untitled, Age 9 Years, 5 Months.}

Growing things are everywhere and every day brings a new life

$$
\begin{gathered}
\text { to Earth } \\
\text { which grows } \\
\text { and grows } \\
\text { until it reaches } \\
\text { its full height } \\
\text { it takes a last breath } \\
\text { and lies down } \\
\text { a new life }
\end{gathered}
$$

is born 
In this final poem, the author connects her recurrent theme of Earth to her understanding of life and the life cycle. She returns to the idea she first presented earlier in poem 1, but with a new cognitive ability to represent systems of ideas, recurring in patterns. Whereas at age 6 she could relate one grand idea (strong and enduring love for her brother) to another grand idea (the Earth spinning over time), here she can understand that many smaller processes come together to make a bigger cycle. This cycle also invokes more complex emotional consequences for the reader than the earlier poems do, starting with a celebration of growing things, passing through the process of dying, and returning to the hopefulness of new life. She accomplishes this increased emotional complexity also through her developing sense of structure, going beyond the conventional framing she used in poems 2 and 3 and instead chopping her phrases with line breaks and indents to mark new, impactful ideas.

In conclusion, to tie these poems together, we can see that they exemplify nicely the role of what Antonio Damasio and I termed "emotional thought" in the accompanying article. Even the most dry and concrete factual knowledge about the world, for example facts about the workings of the physical planet on which we live, gains power when it is connected to this young author's social and emotional relationships and values. Her disciplinary knowledge of science becomes a source of metaphors for understanding and describing the social world, as well as the other way around-she uses the familiar feelings of social bonds to understand and appreciate the natural world. As she grows and builds more and more abstract disciplinary knowledge, knowledge that is separate from her social relationships, perhaps the childhood connections she once felt between her understanding of the physical world and the social experience of living on it will remain a source of inspiration.

\section{Notes}

All poems are written by Nora Ming-Min Yang.

Many thanks to Denny Blodget and Joanna Christodoulou for their comments on an earlier version of this essay. 


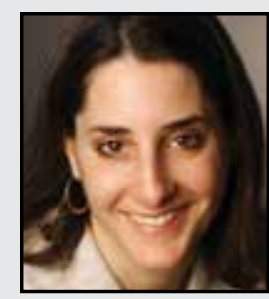

Mary Helen Immordino-Yang is an affective neuroscientist and human development psychologist who studies the neural, psychophysiological and psychological bases of emotion, social interaction and culture and their implications for development and schools. She is an Assistant Professor of Education at the Rossier School of Education, an Assistant Professor of Psychology at the Brain and Creativity Institute, and a member of the Neuroscience Graduate Program Faculty at the University of Southern California. She is the Associate Editor for North America for the award-winning journal Mind, Brain and Education, and the inaugural recipient of the Award for Transforming Education through Neuroscience.

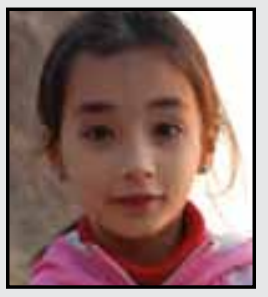

Nora Ming-Min Yang is a fourth grade student living with her mom, dad, and little brother in Southern California. She is a budding poet, pianist, and yogi who loves playing with her friends, hiking and camping with her family, and competing on a Girl Scouts robotics team.

\section{LINKTO:}

http://www-bcf.usc.edu/ immordin/ 